\title{
Critical vulnerabilities of marine and sea ice-based ecosystems in the high Arctic
}

\author{
Ola M. Johannessen • Martin W. Miles
}

Accepted: 10 November 2010/Published online: 1 December 2010

(C) The Author(s) 2010. This article is published with open access at Springerlink.com

\begin{abstract}
The objectives of this paper are to summarise: (1) observed 20th-century and projected 21st-century changes in key components of the Arctic climate system and (2) probable impacts on the Arctic marine environment, with emphasis on the vulnerabilities of marine and sea ice-based ecosystems. Multi-decadal to century-scale observational data sets of surface air temperature (SAT) and sea ice indicate that the two pronounced 20th-century warming events, both amplified in the Arctic, were linked to sea-ice variability. Arctic sea-ice coverage has decreased $\sim 8 \%$ in the past quarter century, with record- and nearrecord low summer ice in observed recent years. A set of coupled atmosphere-ice-ocean global model simulations quantifies the expected changes in Arctic temperature and sea ice through the twenty-first century. Projected are polar-amplified increases in SAT and reductions in sea ice, with a predominantly ice-free Arctic Ocean in summer projected before the end of this century. A range of potential consequences of Arctic warming and a shrinking ice cover are foreseen. First, exposure of vast areas of the
\end{abstract}

O. M. Johannessen ( $\square)$

Nansen Environmental and Remote Sensing

Center/Mohn-Sverdrup Center for Global Ocean Studies

and Operational Oceanography, Bergen, Norway

e-mail: ola.johannessen@nersc.no

\section{O. M. Johannessen}

Geophysical Institute, University of Bergen, Bergen, Norway

\section{W. Miles}

Uni Research - Bjerknes Centre for Climate Research, Bergen, Norway

M. W. Miles

Environmental Systems Analysis Research Center,

Boulder, CO, USA
Arctic Ocean would greatly alter the coastal and shelf marine environment. Second, broad changes in the marine and sea ice-based ecosystem-e.g. changes in plankton due to less ice and greater inflow of melt water-could negatively impact Arctic and sub-Arctic marine biodiversity, not least the vulnerable ice-based mammals such as polar bears. Third, there would be a larger open area for potential Arctic fisheries, as well as increased offshore activities and marine transportation, including the Northern Sea Route north of Siberia. Changes in the physical environment of the Arctic Ocean are thus expected to be dramatic, and although projecting ecosystem changes several decades into twenty-first century is challenging, the impact of diminishing sea ice on Arctic marine and sea ice-based ecosystems will certainly be transformative.

Keywords Arctic · Greenland - Sea ice - Marine ecosystems · Fisheries

\section{Introduction}

The Arctic is a key region in the earth's climate system, both as a sensitive responder and as an active player in global climate change. The Arctic Ocean and particularly its adjacent shelf seas have enormous biological and other resources (e.g. hydrocarbon reserves). The purpose of this paper is to provide a timely overview of: (1) observed and projected changes in key components of the Arctic climate system (e.g. sea-ice cover) and (2) potential impacts and critical vulnerabilities of the Arctic marine environment and its ecosystem to climate change.

Recent and projected changes in the key Arctic atmosphere-ice-ocean climate-system components such as air temperature and sea ice are presented in section "Recent 
and future changes in the Arctic climate system". Attention is given to the expected changes in temperature and sea ice at specific time intervals in the twenty-first century. Section "Impacts" describes the potential impacts and critical vulnerabilities of Arctic marine environment and ecosystem to physical changes in major components of the Arctic climate system, with separate descriptions for marine and sea ice-based ecosystems ("Marine and sea ice-based ecosystems"), fisheries ("Fisheries") and marine transportation and offshore activities ("Arctic marine transportation and offshore activities"). Concluding remarks are provided in section "Conclusions".

\section{Recent and future changes in the Arctic climate system}

Recent syntheses of multi-variate observational data of atmospheric, oceanic, cryospheric and other climatesensitive variables have concluded that a coherent portrait of changes in the Arctic is apparent in the last few decades, particularly in the 2000s (e.g. Johannessen et al. 2004b; Overland et al. 2004; ACIA 2005; Anisimov et al. 2007). Here, we describe recent and projected changes in three key aspects of the Arctic climate system: (1) air temperature; (2) sea ice; and (3) ice melt, freshwater and ocean circulation.

\section{Air temperature}

The Arctic and sub-Arctic are the regions expected to warm the most in response to anthropogenic increases in the atmospheric concentration of greenhouse gases (GHGs). There is observational evidence that Arctic surface air temperature (SAT) changes have been amplified during two strong warming periods, the 1920s-1930s and the 1970s to present (Fig. 1). The earlier warming was caused by the natural internal variability of the climate system. The recent ongoing warming since the 1970s is broader and caused primarily by the dramatic increase of GHGs over the last

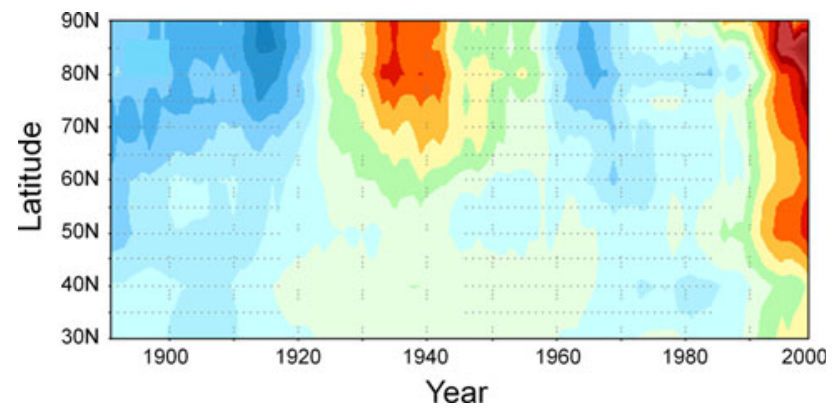

Fig. 1 Hovmöller diagram indicating the time-latitude variability of observed surface air temperature (SAT) anomalies north of $30^{\circ} \mathrm{N}$, 1891-1999 (Johannessen et al. 2004a) few decades (Bengtsson et al. 2004; Johannessen et al. 2004b), although natural modes of variability have played a role in the strong Arctic winter warming since 2000 (Overland et al. 2008). Winter warming in the northern high-latitude regions by the end of the century is projected to be on the order of $50 \%$ greater than the global mean based on models and emissions scenarios assessed in the Intergovernmental Panel on Climate Change third and fourth assessment reports (IPCC 2001, 2007). Warming projected for the central Arctic is $\sim 3-4^{\circ} \mathrm{C}$ during the next 50 years, more than double the global mean.

The expected changes in SAT at different time intervals in the future can be derived from the sets of projections summarised in Fig. 2. The models have been run with two scenarios from the IPCC Special Report on Emissions Scenarios (SRES) (Nakicenovic and Swart 2000), A2 and B2, which are "medium-high" and "medium-low" scenarios, respectively. The results support the polar amplification hypothesis and suggest that Arctic mean temperatures will increase by $\sim 3^{\circ} \mathrm{C}$ by the 2040s under the $\mathrm{B} 2$ scenario, even $4^{\circ} \mathrm{C}$ under the $\mathrm{A} 2$ assumption. By the 2080 s, these numbers increase to about 4 and $6{ }^{\circ} \mathrm{C}$. Seasonal differences (not shown) are projected to be large, as are regional differences.

Sea ice

Sea-ice extent (area within the ice-ocean margin) in the Arctic has been monitored regularly using aircraft and satellite images over the last several decades, however with improved accuracy since 1978 with the advent of satellite remote sensing using multi-channel passive-microwave sensors. In the 1990s, several trend analyses using these data to retrieve sea-ice concentration indicated that the total ice area (extent $x$ ice concentration) decreased by

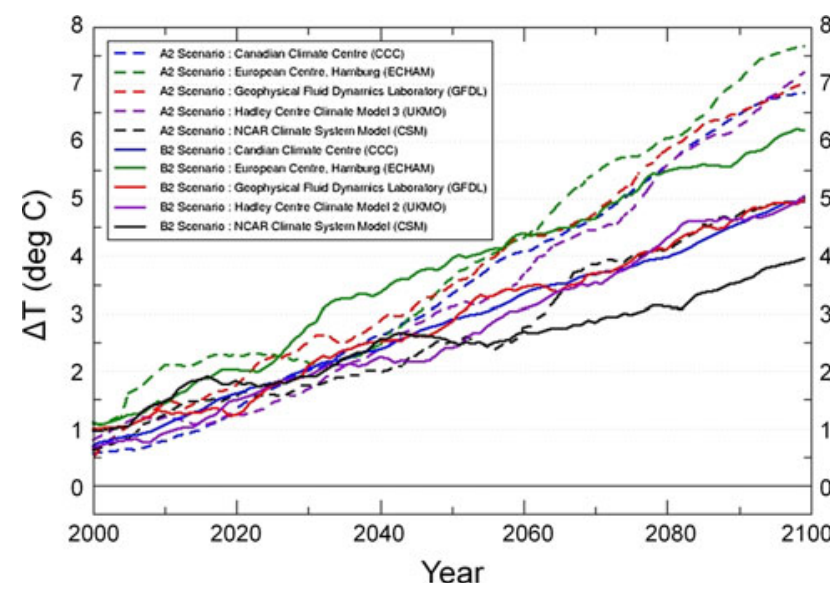

Fig. 2 Model-predicted changes in Arctic SAT through the twentyfirst century, based on five general circulation models (GCMs) and two scenarios from the IPCC Special Report on Emissions Scenarios (SRES): A2 (dashed lines) and B2 (solid lines). Source: ACIA (2005) 


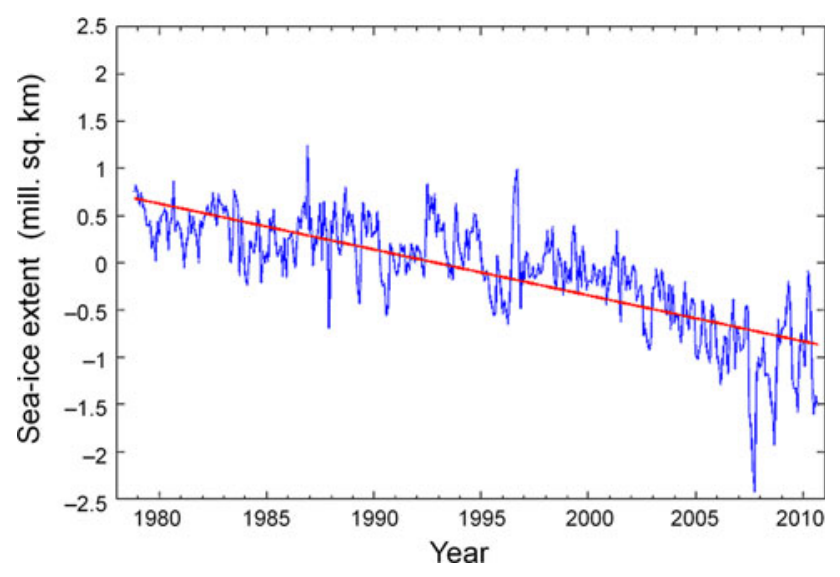

Fig. 3 Arctic sea-ice extent anomalies and trend, derived from satellite passive-microwave sensor data, 1979-2010. Source: ArcticROOS, http://arctic-roos.org/observations

approximately 3-4\% per decade from 1978 through the mid-to-late 1990s (e.g. Bjørgo et al. 1997; Johannessen et al. 1999). Meanwhile, the area of the relatively thick perennial ("multi-year") ice decreased by $7 \%$ per decade, suggesting an ice cover in transformation (Johannessen et al. 1999). Temporally, trends have been negative for all seasons, though largest in summer. In the most recent years, the summer (September) minimum ice extent has decreased substantially, with record low minima occurring in 2002 and 2005-and subsequently with 2007 setting a new record by about $24 \%$ (Fig. 3). Several research groups now regularly monitor and analyse sea-ice variability and trends in near-real time. An Arctic Regional Ocean Observing System (Arctic ROOS) has been established by a group of 14 member institutions from nine European countries working actively with ocean observation and modelling systems for the Arctic Ocean and adjacent seas.
Arctic ROOS promotes, develops and maintains operational monitoring and forecasting of ocean circulation, water masses, ocean surface conditions, sea ice and biological/chemical constituents. Arctic ROOS and other groups have identified the summer minima in 2008-10 to be been only moderately higher than in 2007, having "rebounded" to the long-term linear negative trend line. Spatially, winter decreases have been greatest in the Barents and Greenland Seas and the Sea of Okhotsk, whereas summer decreases have been largest in the Beaufort and Siberian seas, as indicated in Fig. 4.

The spatial and seasonal variability of the ice cover and its response to anthropogenic forcing has been modelled through the year 2100, using two different state-of-the-art models including different IPCC SRES emissions scenarios (Johannessen et al. 2004a). The models employed were the ECHAM-4 and HadCM3, from the Max-Planck Institute for Meteorology, Hamburg, Germany, and the Hadley Centre at the UK Met Office, respectively. These model experiments have been run until the atmospheric concentration of $\mathrm{CO}_{2}$ has doubled with regard to the present concentration.

The spatial distributions of the ECHAM4 and HadCM3 model-projected ice cover in the twenty-first century are shown in Figs. 5 and 6, respectively. The ECHAM4 results are shown here for two decadal time intervals: 2000s and 2080s (Fig. 5). These results are from model runs using the IPCC IS92 emission scenario, which is comparable to IPCC SRES scenario B2. The HadCM3 results are shown for five decadal time intervals: 2000s, 2020s, 2040s, 2060s and 2080s (Fig. 6). The HadCM3 results shown here are those using IPCC SRES emissions scenario B2, although results using the higher A2 scenario have also been produced. The key common feature is the projection of moderate changes
Fig. 4 Spatial patterns of linear trends (\%) in Arctic sea-ice concentration, retrieved from satellite passive-microwave sensor data, 1979-209/10, in a winter (March) and b summer (September). Source: National Snow and Ice Data Center (NSIDC), Boulder, CO, USA
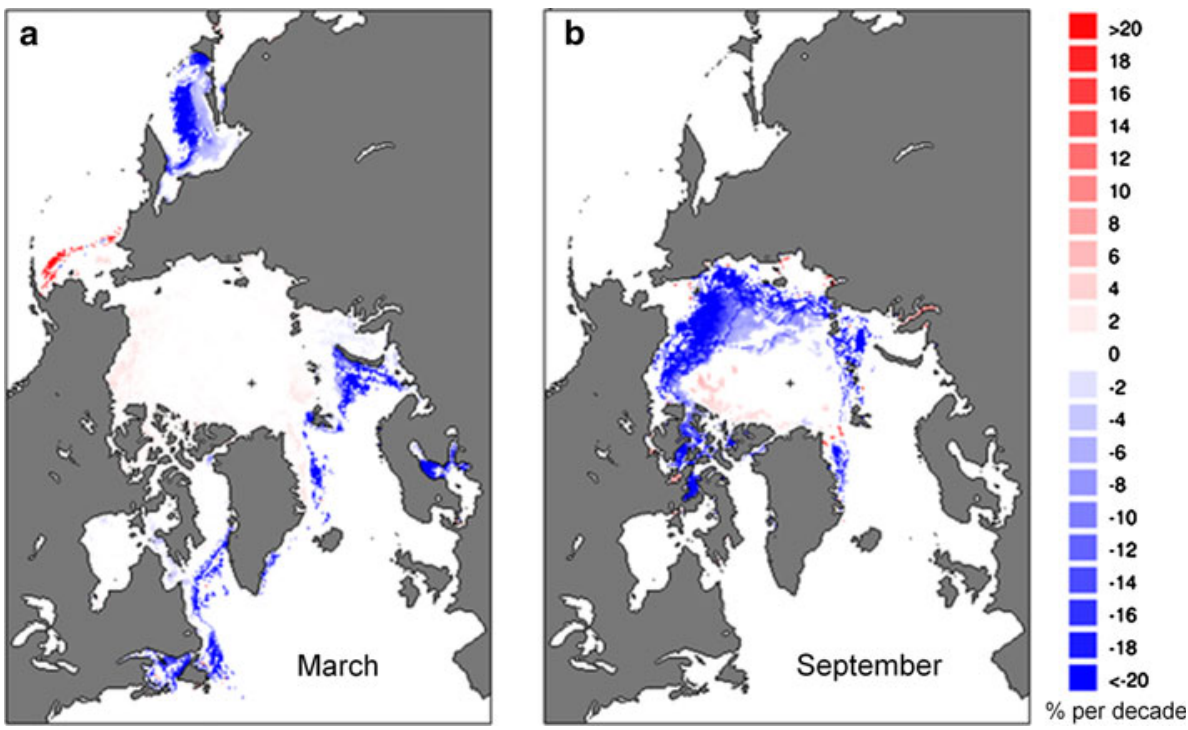

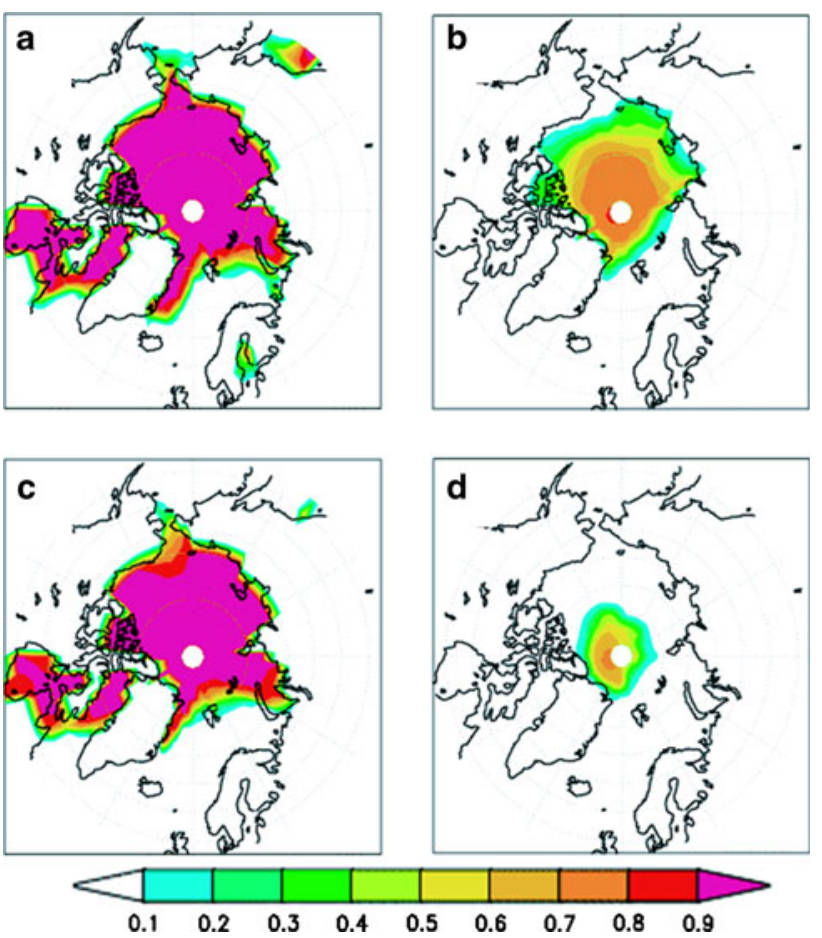

Fig. 5 ECHAM4 model-projected Northern Hemisphere sea-ice concentration (tenths) in late winter (March) in two decadal time intervals a 2001-2010 and c 2081-2090 and in late summer (September) from b 2001-2010 and d 2081-2090. Results shown here are using the IPCC IS92 emission scenario, comparable to IPCC SRES scenario B2. Source: Johannessen et al. (2004a)

in winter and drastic changes in summer, with up to an $80 \%$ reduction expected late in the century.

These model results and other results from Johannessen et al. (2004b) have been taken into the Arctic Climate Impact Assessment report (ACIA 2005) and IPCC Fourth Assessment Report (IPCC 2007). The ACIA report went further by including composite results from additional models (e.g. Walsh and Timlin 2003) and computing the five-model mean projected spatial fields at time periods 2010s-2020s, 2040s-2060s and 2070s-2080s. The overall mean is slightly greater than the HadCM3 results at comparable time periods, though model-to-model spatial variability is large.

However, the strong declines in observed sea-ice extent in the past two decades-even ignoring the summer 2007 and 2008 extremes-are faster than those expected by an average of IPCC models (Stroeve et al. 2007). Therefore, alternative approaches have been proposed to predict seaice extent in the coming decades. An empirical approach based on the observed strong correlation $\left(r^{2} \sim 0.9\right)$ between sea-ice extent and atmospheric concentrations of $\mathrm{CO}_{2}$ has been developed (Johannessen 2008). When applied to future emission scenarios, this relationship results in substantially faster ice decreases up to 2050 than predicted by IPCC models (Fig. 7). Another alternative analysis employs a select subset of IPCC models and uses the observed 2007/2008 September sea-ice extent as an adjusted starting point, predicting a nearly ice-free (less than 1 mill. sq. km) Arctic in September by the year 2037 (Wang and Overland 2009). Finally, the issue of whether there may be a critical threshold or "tipping point" for the Arctic ice cover that could hasten its demise is a matter of debate.

Ice melt, freshwater and the meridional ocean circulation

The Greenland Ice Sheet has received increased attention for at least two reasons related to global climate change (IPCC 2001; ACIA 2005; Johannessen et al. 2005; IPCC 2007). First, eventual complete melting of the ice sheet would raise the global sea level up to $7 \mathrm{~m}$. This process, expected to occur on a millennial time scale, should begin when the critical $\sim 3^{\circ} \mathrm{C}$ threshold for Greenland regional climate warming is crossed, probably before the end of this
Fig. 6 HadCM3 modelprojected Northern Hemisphere sea-ice concentration (tenths) in winter (upper panels) and summer (lower panels) in five decadal time intervals. Results shown here are using the IPCC SRES B2 emissions scenario.

Source: Modified from Johannessen et al. (2004a). Courtesy Dr. Howard Cattle, Hadley Centre, Met Office, UK
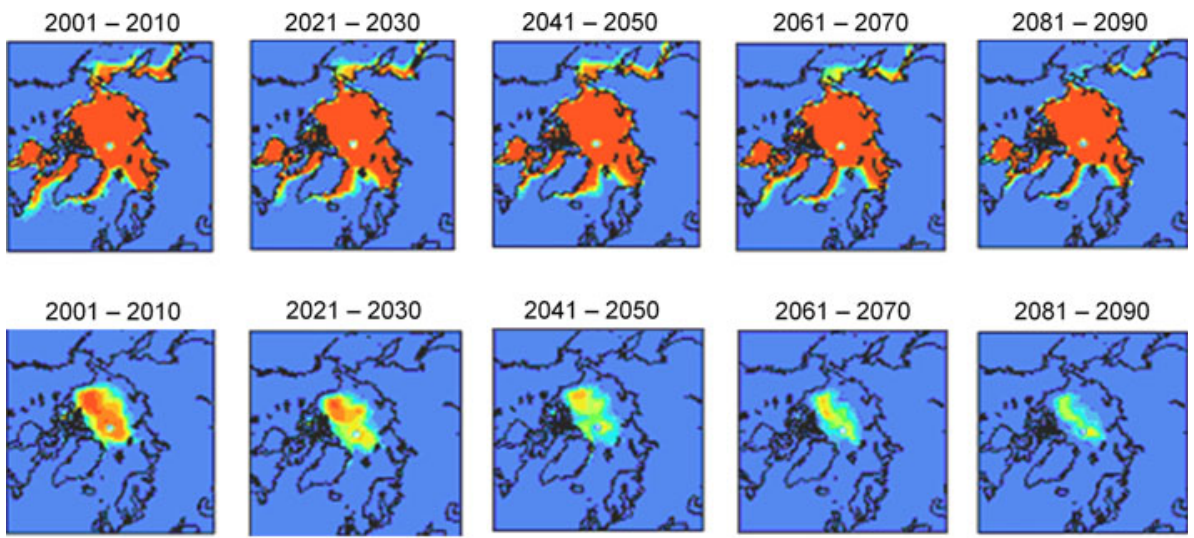

$\begin{array}{lllll}0.1 & 0.3 & 0.5 & 0.7 & 0.9\end{array}$ 


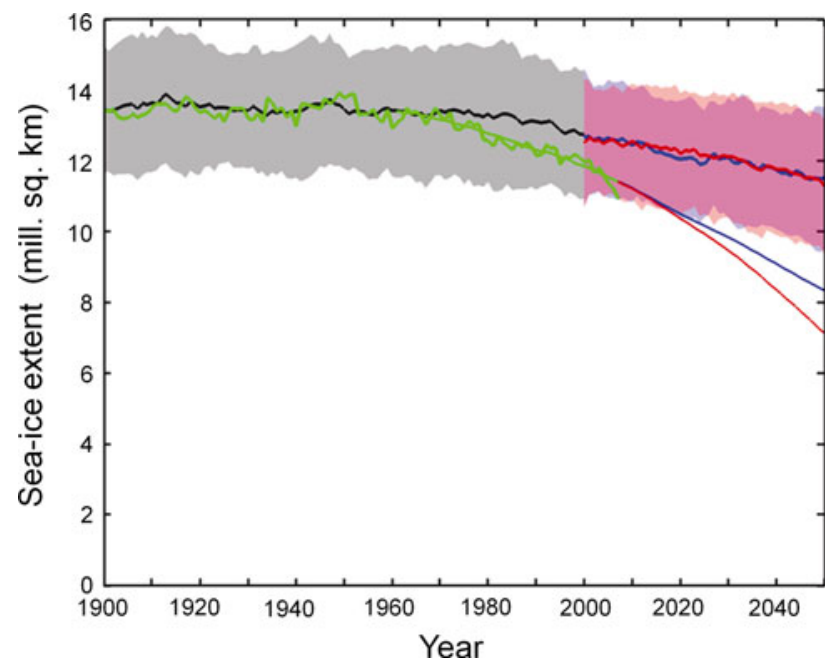

Fig. 7 Arctic annual sea-ice extent 1900-2007 (observed-green, and IPCC modelled mean ensemble-black) and predictions for 2007-50 under projected CO2 scenarios of the IPCC. The ensemble mean of 15 IPCC numerical-model experiments are thick lines: B1blue; A2-red. Shading indicates \pm 1 s.d. uncertainty. Empirical model projections (Johannessen 2008) are also shown as thin lines, B1-blue; $\mathrm{A} 2$-red. The projections are based on a linear regression of $\mathrm{CO}_{2}$ and sea-ice extent data from 1961-2007. The empirical projection does not include natural fluctuations that would be superposed on the trends, as seen in the observations (green)

century (Fichefet et al. 2003; Gregory et al. 2004). Second, a substantially increased freshwater input into the Nordic Seas and northern North Atlantic from a much accelerated Greenland Ice Sheet melt has been theorised to weaken or even disrupt the Atlantic meridional overturning circulation (AMOC) on a relatively rapid, multi-decadal time scale (e.g. Rahmstorf 2000; Schiermeier 2006). This would reduce the heat transport by the Gulf Stream extension to the sub-Arctic and Arctic seas to some degree, possibly offsetting the Arctic warming, at least regionally. However, indications of a reasonably stable AMOC over the next 150 years are found in model experiments that forced a large pulse of freshwater into the Arctic and adjacent Nordic Seas. Otterå et al. (2004) found that changes in the AMOC consist of a multi-decadal reduction of $30 \%$ of the strength, followed by a rebound, suggesting that the system is quite robust. Weakening of the AMOC would reduce warming in the Arctic region and could add to sea level rise on the north-east North America coast (Hu et al. 2009; Yin et al. 2009). The prognosis for the future rate of loss of ice from the Greenland Ice sheet is uncertain. Present rates of loss would need to increase by more than an order of magnitude to bring the increased freshwater input into the Nordic Seas and northern North Atlantic to the point where it would likely affect the AMOC strength according to these studies.
Research using satellite data of ice-sheet surface elevation during the period 1992-2003 indicated that melting and ice discharge apparent in the narrow margins of the ice sheet might be partially compensated by accumulation of snow over the vast elevated highlands during wintertime, at least until 2003 (Johannessen et al. 2005). However, more recent reports (e.g. Rignot and Kanagaratnam 2006) indicate that glacier acceleration has become more widespread such that ice discharge doubled the ice-sheet mass deficit in last decade, from 90 to $220 \mathrm{~km}^{3} \mathrm{yr}^{-1}$, causing an increase of sea level from $0.23 \mathrm{~mm} \mathrm{yr}^{-1}$ in 1996 to $0.57 \mathrm{~mm} \mathrm{yr}^{-1}$ in 2005. If the latter rate were maintained, it would raise sea level by about $6 \mathrm{~cm}$ over 100 years contributing on average around $0.01 \mathrm{~Sv}$ (Sverdrup). Presently, it appears that estimates converge around $200 \mathrm{Gt} / \mathrm{year}$ - equivalent to about $0.6 \mathrm{~mm}$ of the annual 3-mm rise in global sea levelsome a result of enhanced runoff minus accumulation and the remainder a direct result from outlet glacier losses. Icesheet model surface mass balance projections for the loss of ice from Greenland from the IPCC SRES range of scenarios over 100 years were $1-8 \mathrm{~cm}$ (Meehl et al. 2007). A recent attempt to constrain likely loss rates from ice dynamics estimated that to 2,100 losses yielded a range of $16-54 \mathrm{~cm}$ sea level rise, which would contribute 0.02$0.07 \mathrm{~Sv}$ of freshwater on average to 2100. Higher rates of loss may be implied by recent estimates of sea level rise during the last interglacial period of $1.6 \mathrm{~m}$ per century, which would contribute $0.2 \mathrm{~Sv}$ of freshwater on average to 2100. As a result of these uncertainties, Greenland Ice Sheet melt and discharge, as well as increased freshwater input from Arctic rivers (Peterson et al. 2002; Bobylev et al. 2003), must be considered "wildcards" in scenarios of climate change, the AMOC and their impacts on the Arctic and northern Europe.

\section{Impacts}

Here, we summarise the potential impacts on the following: (1) marine and sea ice-based ecosystems, (2) fisheries and (3) marine transportation and offshore activities. These summaries are based on assessments from ACIA (2004) and the EU 5th Framework research project "Arctic Ice Cover Simulation Experiment" (AICSEX), coordinated by the lead author (Johannessen et al. 2004a), reports from research done by the Institute of Marine Research, Bergen and the University of Oslo, Norway, as well as the ongoing Ecosystem Studies of Sub-Arctic Seas (ESSAS) program, which addresses the need to understand how climate change will affect the marine ecosystems and fisheries of the sub-arctic seas and their sustainability (Hunt and Drinkwater 2005). 
Marine and sea ice-based ecosystems

The effects of climate change on Arctic marine ecosystems are twofold-physical and chemical. Here, we address primarily the physical effects, e.g. related to increases in sea temperature, changes in water masses, circulation and the sea-ice cover. The chemical effects, e.g. ocean acidification resulting from atmospheric $\mathrm{CO}_{2}$ uptake, although not discussed here, may also impact Arctic marine ecosystems in the future. The consequences of ocean acidification may affect polar waters first, and moreover, there are indications that conditions adversely impacting high-latitude ecosystems may develop within decades, not centuries, as believed previously (Orr et al. 2005).

\section{Marine food webs and climate}

Arctic and sub-Arctic marine food webs are fundamentally influenced by the coupled ocean-ice-atmosphere system. For example, in the food web for the Barents Sea-which can be described in a simplified manner as consisting of phytoplankton (1st level), zooplankton (2nd level), capelin and herring (3rd level), cod (4th level), seals and whales (5th level)_phytoplankton, capelin, seals, and whales are closely linked to the sea-ice edge. Zooplankton, fish and whales are heavily dependent on the "right" sea temperature. Cloudiness and wind velocities are also important climatic factors (Stenseth et al. 2002). Moreover, all members of the ecosystem are highly dependent of each other, as illustrated in Fig. 8. Therefore, a threshold crossed for one member may substantially affect other members and the Arctic ecosystem as a whole. The exact thresholds in terms of specific temperatures expected at time periods in the future are presently uncertain, although research into temperature dependencies of food web members ranging from some algal to fish species has established some relationships, as described in the followed sections.

\section{Plankton}

The algae growing at the base of the sea-ice cover play an important role in sustaining secondary production, and it is thought that such algae can affect the pelagic food web through their effect on the phytoplankton bloom near the ice edge. Changes in the sea ice and snow cover on the ice may strongly affect these algae and hence the food web (Lavoie et al. 2005). Dramatic changes in plankton and fish resources in the Arctic marginal seas have been related to transitioning from cold to warm periods associated with changes in the position of the sea-ice edge and Atlantic water inflow events. Recent case studies from the Barents Sea show that in a climatically cold year, the zooplankton biomass is highest in the Arctic waters of the north-eastern Barents Sea-due to the increase in larger Arctic amphipod species such as Themisto libellula. In a climatically warm year, the zooplankton biomass is high in the Atlantic waters of the south-western Barents Sea. The large increase in zooplankton biomass in the Atlantic waters was presumably due to the higher inflow of advected organisms, e.g. Calanus spp., as well as high temperatures, which may lead to high growth rates of zooplankton.

\section{Marine mammals}

Most species of Arctic marine mammals depend on the presence of sea ice, at least seasonal ice and in some cases perennial ice. The marginal sea-ice edge zone moves 1000s
Fig. 8 Schematic diagram of an Arctic marine ecosystem (centre), exemplified by the Barents Sea. Also indicated are the key climatic factors influencing the food web in the region. Modified from Stenseth et al. (2002)

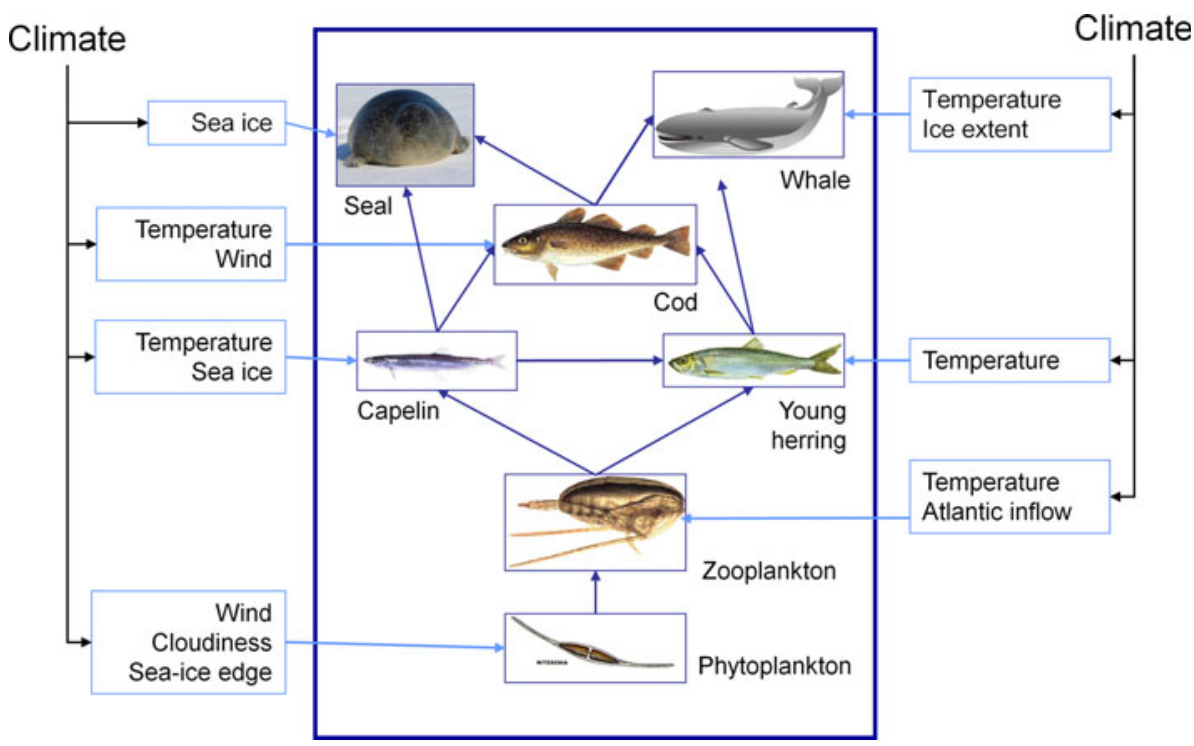


of kilometres each year. Walruses and numerous species of seals and whales all follow the ice edge, taking advantage of the ready access to food and (for seals and walrus) the availability of ice for sunning, mating and raising pups. Keystone marine mammals (e.g. ice-based seals, walrus and polar bears) are thus highly vulnerable to ice reductions, as projected for the twenty-first century. Walrus and seals are particularly vulnerable, in that retreat of the ice edge beyond the shelf to deep waters of the Arctic Ocean would be disastrous for both these marine mammals. Inuit hunters are noticing thinning of sea ice, changes in the leads and open water areas, and the presence of animals not previously found in the region. The ACIA report (2005) warns that early impacts of climate change, such as melting sea ice and glaciers, are already apparent and "will drastically shrink marine habitat for polar bears, ice-inhabiting seals and some seabirds, pushing some species towards extinction". Since the ACIA report, the accelerated decrease in the summer sea-ice cover, particularly the drastic reduction in 2007, may have lead to the US recognition in 2008 that the polar bear is indeed a "threatened" species (Anonymous 2008).

The climate-change thresholds and the commensurate time periods in the future that are critical for marine mammals are uncertain for at least two reasons. Firstly, the modelled sea-ice scenarios for several decades in advance are themselves uncertain, particularly on a regional scale. Nonetheless, the summer sea-ice cover is expected to be diminished and far from the coasts and probably off the shelves, except for the Canadian Arctic Archipelago and northern Greenland (Figs. 5, 6). This is apparent in most models by mid-century (e.g. under the assumption of $\sim 3^{\circ} \mathrm{C}$ warming, B2 scenario in Fig. 2). Secondly, the marine mammals are inextricably dependent on the lowerlevel food web members, such that changes in fish distributions resulting from climate warming will also make the marine mammals more vulnerable.

\section{Fisheries}

The sub-Arctic seas presently have some of the planet's largest and most productive fisheries. There is a need to understand how climate change will affect the marine ecosystems and fisheries of the sub-Arctic seas and their sustainability (Hunt and Drinkwater 2005). The fisheries of the Barents Sea and the adjacent Norwegian Sea have been relatively well researched with respect to climatic variability and its impacts. The impact of climate change on Arctic fisheries can be exemplified by the Barents Sea region, which is responsible for $20 \%$ of the fish catch in the world. Therefore, we focus on this region with examples drawn primarily from Norwegian research on cod.
The variability in the physical conditions such as the sea-ice distribution, water-mass distribution and ocean circulation pattern will directly or indirectly-through food web linkages (Fig. 7)_impact the fish stocks in the Arctic. Climatic variations affect several fish-stock parameters: (1) growth, (2) spatial distribution, (3) migration and (4) recruitment. Climate fluctuations affect fish directly, as well as by causing changes in their biological environment (predators, prey, species interactions and disease). Direct physiological effects include metabolic and reproductive processes. Climate variability may influence the abundance in fish populations, principally through effects on recruitment. The physical environment also affects feeding rates and competition through favouring one or another species, as well as the abundance, quality, size, timing, spatial distribution and concentration of food. It also affects predation through influences on the abundance and distribution of predators.

Sea temperature is considered the primary source of environmental impact on fish, although salinity conditions, mixing and transport processes in the ocean are also important. The biomass of zooplankton, the main food for larval and juvenile fish, is generally greater when temperature is high in the Norwegian and Barents Seas. High food availability for the young fish results in higher growth rates and greater survival through the vulnerable stages that determine the strength of a year-class. Temperature also affects the development rate of the fish larvae directly and, consequently, the duration of the high-mortality and vulnerable stages decreases with higher temperature (Ottersen and Loeng 2000). Furthermore, in the Barents Sea, mean body size as half-year olds for herring, haddock and cod and length of all three species is positively correlated with sea temperature. This indicates that these species, having similar spawning and nursery grounds, respond in a similar manner to large-scale climate fluctuations (Ottersen and Loeng 2000); e.g. for Barents Sea cod, mean lengths-at-age are greater in warm periods (Michalsen et al. 1998). It has been shown that for all three stocks, there is a connection between length at the 0-group stage and year-class strength both as 0-group and as 3-year olds. The length of the 0-group cod is closely related to the mean annual temperature of the Kola section (running north from the Kola Peninsula along $33^{\circ} 30^{\prime} \mathrm{E}$ into the Barents Sea) indicating higher growth at higher temperatures. There is also a clear connection between the temperature and the Barents Sea herring stock, based on data from the Kola section (Toresen and Østvedt 2000).

The Barents Sea cod has a long route of pelagic drift $(600-1,200 \mathrm{~km})$ from the spawning ground to areas where bottom settlement occurs. Five months after spawning, the small fish spread out in the entire Atlantic water masses of 
the Barents Sea and partly above the narrow shelf region off the coast of West Spitsbergen. Ottersen and Sundby (1995) showed that southerly wind anomalies throughout the period of pelagic drift from the main spawning grounds in the Lofoten area in northern Norway to the nursery grounds in the Barents Sea leads to above average yearclass strength. This was interpreted as being partly a temperature effect and partly an effect of added influx of zooplankton-rich water from the Norwegian Sea into the feeding areas of the Barents Sea.

In determining the large-scale distribution pattern of fish, temperature is thus one of the primary factors, together with food availability and suitable spawning grounds. In the Barents Sea, temperature-related displacement of cod has been reported on an inter-annual time scale as well as on both small and large spatial scales. In periods of warm climate, the cod distribution is extended towards the east and north when compared to colder periods when the fish tend to concentrate in the south-western part of the Barents Sea (Ottersen et al. 1998).

As a possible analogue for twenty-first century warming impacts, one may point out that Atlantic cod moved northward along western Greenland in response to pronounced warming in the 1920s-30s (Jensen 1939). Model scenarios for the twenty-first century suggest that SAT increases of $2-4^{\circ} \mathrm{C}$ may be expected by 2100 in most regions presently occupied by cod, with the Barents Sea warming by up to $6^{\circ} \mathrm{C}$ (IPCC 2001). Translating these projected changes into critical thresholds for impact on the cod is difficult, though it has been suggested that for a $3-4^{\circ} \mathrm{C}$ increase would not decrease the northern cod, e.g. Barents Sea and Greenland, but rather adversely affect those in the northern North Atlantic (Drinkwater 2005).

Expected twenty-first century changes in the environmental conditions will thus have enormous consequences for the fish stocks in polar and sub-polar regions. Historical data generally indicate that increased temperatures tend to generate positive recruitment and positive individual growth for most fish stocks. Therefore, some stocks will be able to recruit better with an increased temperature, at least on the short term. On the other hand, increased fish density might lead to reduced growth and worse living conditions, which again will decrease the recruitment on a longer term. Different fish stocks naturally have different preferences for temperature, such that changes in the temperature in the ocean might lead to a different distribution of the different fish stocks than they have today and that traditional good fishing areas might be less productive in the future. Research suggests that climate change can alter fish stocks in the Barents Sea by $25 \%$ in either direction, making it difficult to project whether to expect beneficial or detrimental impacts.
Toresen and Østvedt (2000) suggested how a warmer climate might influence the distribution of common fish stocks. As a consequence of the warming, the seasonal ice zone will also move further north during winter. Warming will also lead to an eastward migration of cod, haddock, herring and capelin. Fishing grounds that traditionally have been productive can have reduced influence because of the warming. A greater part of the cod will reside in the Russian economic zone, and the capelin will move further north-east in the Barents Sea, in particular during autumn. The capelin will still spawn along the Norwegian coast. It has not been shown that capelin recruitment is better at increased temperatures; however, the growth can be better. In an apparent paradox, this may lead to a smaller stock because more rapid growth can lead to earlier spawning, and thereafter most of the capelin die. If the increase in temperature leads to an increased occurrence of good herring year-classes, the progress of herring will inhibit recruitment of capelin. In this case, the net result would be a long-term reduction in the capelin stock.

\section{Arctic marine transportation and offshore activities}

The Northern Sea Route (NSR), or the North-east Passage, is the shortest sea route from Europe to the Pacific Ocean and the Asia. However, difficult ice conditions present a natural obstacle to traffic. The period for navigation in icefree open waters near the coast presently lasts only from August to October (Johannessen et al. 2007). During this period, however, the NSR is of great importance to the domestic service transports of northern Russia. If there is

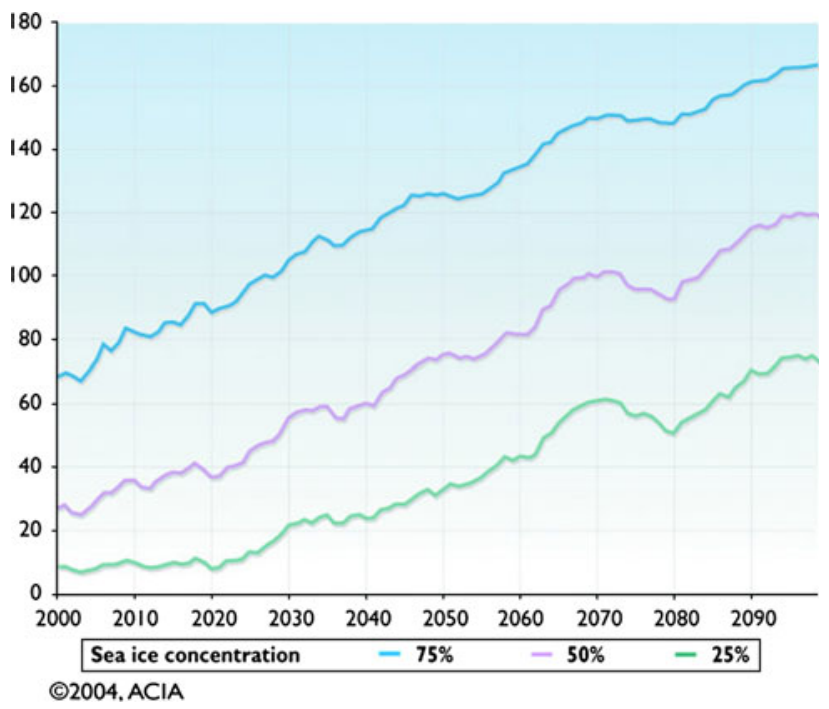

Fig. 9 Increase in length of the season for navigation through the Northern Sea Route, as an average of five ACIA model projections. The effective length of season is shown to depend on the navigability of different vessels through various ice concentrations $(25,50$ and $75 \%)$. Source: ACIA (2005) 
less and/or thinner ice in the future, the NSR can be used for a longer period of the year (Johannessen et al. 2004a). An illustration of the increase in length of the season for navigation through the NSR, as an average of five ACIA model projections is found in Fig. 9.

Less sea ice in the Arctic will also allow for exploration and production of oil and gas under more favourable conditions. The Barents Sea is one of the hot spots in these scenarios. These activities may eventually adversely impact the marine ecosystem in the event of pollution discharges, e.g. oil spills, and eventually through furthering greenhouse emissions through burning the oil and gas extracted from the seabed.

\section{Conclusions}

Recent and projected changes in the Arctic ocean-iceatmosphere climate system include: (1) increasing warmth in the lower atmosphere and the ocean; (2) decreasing sea ice, particularly in summer in the most recent years; (3) increasing Arctic river runoff; and (4) increased melting in the low-elevation regions of the Greenland ice sheet. However, there are 'wildcards' in the climate system that may potentially change these trends, namely the fate of the Greenland Ice Sheet as a freshwater source and the state of the MOC in the northern North Atlantic.

The potential impacts of 21st-century climate change on the Arctic marine environment and its ecosystems are anticipated to be significant, even transformative. The reasons are due to both the amplified magnitude of temperature changes in the Arctic (Sect. "Air temperature") and the reduction in the sea-ice cover (Sect. "Sea ice") on the one hand and to the particular vulnerability of the Arctic marine ecosystems on the other hand. The projected impacts on the natural and human conditions in the Arctic are many and wide ranging (ACIA 2005). The most pertinent for arctic ecosystems and human activities include: increasing coastal erosion; increasing marine transportation and offshore activities (e.g. Northern Sea Route); broad changes in Arctic marine ecosystems, e.g. enhanced productivity at the base of food chain (but a decline in underice algae); and changes in Arctic fisheries that are probably large, but difficult to project. Large-scale changes-e.g. northward shifts of several degrees latitude - in the distribution of biologically and commercially important fish species are expected in the future, with some Arctic fisheries expected to be more productive. On the other hand, the anticipated reduction in the summer sea-ice cover during the twenty-first century portends a challenging future for large, sea ice-based marine mammals such as the polar bear.
Acknowledgement We acknowledge the European Commission's support through the EU Descartes Prize laureate award in earth sciences 2005 for the project Climate and Environmental Change in the Arctic (CECA) led by Ola M. Johannessen (http://www.nersc.no). We also acknowledge funding from the Research Council of Norway (projects MACESIZ, ROLARC and RAPID Greenland Ice Sheet) and support through base funding for the Mohn-Sverdrup Center for Global Ocean Studies and Operational Oceanography at the Nansen Center in Bergen. We thank Cathrine Myrmehl for contributing to the paper.

Open Access This article is distributed under the terms of the Creative Commons Attribution Noncommercial License which permits any noncommercial use, distribution, and reproduction in any medium, provided the original author(s) and source are credited.

\section{References}

ACIA (ed) (2005) Arctic climate impact assessment. ACIA scientific report. Cambridge University Press, New York

Anisimov OA, Vaughan DG, Callaghan T, Furgal C, Marchant H, Prowse TD H, Vilhjálmsson H, Walsh JE (2007) Polar regions (Arctic and Antarctic). In: Parry ML, Canziani OF, Palutikof JP, van der Linden PJ, Hanson CE (eds) Climate change 2007: impacts adaptation and vulnerability. Contribution of working group ii to the fourth assessment report of the intergovernmental panel on climate change. Cambridge University Press, Cambridge, pp 653-685

Anonymous (2008) Two symbols, one solution. Nature 453(7194): 427

Bengtsson L, Semenov VA, Johannessen OM (2004) The early twentieth-century warming in the Arctic-A possible mechanism. J Clim 17(20):4045-4057

Bjørgo E, Johannessen OM, Miles MW (1997) Analysis of merged SMMR-SSMI time series of Arctic and Antarctic sea ice parameters 1978-1995. Geophys Res Lett 24(4):413-416

Bobylev LP, Kondratyev KY, Johannessen OM (2003) Arctic environment variability in the context of global change. Springer, Chichester

Drinkwater KF (2005) The response of Atlantic cod (Gadus morhua) to future climate change. ICES J Mar Sci: Journal du Conseil 62(7):1327-1337

Fichefet T, Poncin C, Goosse H, Huybrechts P, Janssens I, Le Treut H (2003) Implications of changes in freshwater flux from the Greenland ice sheet for the climate of the 21st century. Geophys Res Lett 30(17):1911

Gregory JM, Huybrechts P, Raper SCB (2004) Climatology: threatened loss of the Greenland ice-sheet. Nature 428(6983): 616

Hu A, Meehl GA, Han W, Yin J (2009) Transient response of the MOC and climate to potential melting of the Greenland Ice Sheet in the 21st century. Geophys Res Lett 36:L10707

Hunt GL Jr, Drinkwater KF (eds) (2005) Ecosystem studies of subArctic seas (ESSAS). Science plan. GLOBEC Report No. 19

IPCC (2001) Houghton JT, Ding Y, Griggs DJ, Noguer M, van der Linden PJ, Dai X, Maskell K, Johnson CA (eds) Climate change 2001: the scientific basis. Contribution of working group I to the third assessment report of the intergovernmental panel on climate change (IPCC). Cambridge University Press, Cambridge

IPCC (2007) Solomon S, Qin D, Manning M, Chen Z, Marquis M, Averyt KB, Tignor M, Miller HL (eds) Climate change 2007: the physical science basis. Contribution of working group I to the 
fourth assessment report of the intergovernmental panel on climate change. Cambridge University Press, Cambridge

Jensen AS (1939) Concerning a change of climate during recent decades in the Arctic and sub-Arctic regions, from Greenland in the west to Eurasia in the east, and contemporary biological and geophysical changes. Biologiske Meddelelser 14:75 p

Johannessen OM (2008) Decreasing Arctic sea ice mirrors increasing $\mathrm{CO}_{2}$ on decadal time scale. Atmos Oceanic Sci Lett 1:51-56

Johannessen OM, Shalina EV, Miles MW (1999) Satellite evidence for an Arctic sea ice cover in transformation. Science 286(5446):1937-1939

Johannessen OM, Bengtsson L, Mikolajewicz U, Semenov VA, Sein D, Laxon S, Potter R, Wadhams P, Hughes N, Doble M, Mognard N, Kouraev A, Alenius P, Haapala J, Lygre K, Eldegard T, Myrmehl C (2004a) AICSEX final assessment synthesis report. AICSEX, Bergen, Norway. http://www.nersc. no/AICSEX

Johannessen OM, Bengtsson L, Miles MW, Kuzmina SI, Semenov VA, Alekseev GV, Nagurnyi AP, Zakharov VF, Bobylev LP, Pettersson LH, Hasselmann K, Cattle HP (2004b) Arctic climate change: observed and modelled temperature and sea-ice variability. Tellus A 56(4):328-341

Johannessen OM, Khvorostovsky K, Miles MW, Bobylev LP (2005) Recent ice-sheet growth in the interior of Greenland. Science 310(5750):1013-1016

Johannessen OM, Alexandrov VYu, Frolov IYe, Bobylev LP, Sandven S, Pettersson LH, Kloster K, Smirnov VG, Mironov YeU, Babich, NG (2007) Remote sensing of sea ice in the Northern Sea Route: studies and applications. Springer, Heidelberg

Lavoie D, Denman K, Michel C (2005) Modeling ice algal growth and decline in a seasonally ice-covered region of the Arctic (Resolute Passage, Canadian Archipelago). J Geophys Res 110:C11009

Meehl GA, Stocker TF, Collins WD, Friedlingstein P, Gaye AT, Gregory JM, Kitoh A, Knutti R, Murphy JM, Noda A (2007) Global climate projections. In: Solomon S, Qin D, Manning M et al (eds) Climate change 2007: the physical science basis. Contribution of working group I to the fourth assessment report of the intergovernmental panel on climate change. Cambridge University Press, Cambridge, pp 747-846

Michalsen K, Ottersen G, Nakken O (1998) Growth of North-east Arctic cod (Gadus morhua L.) in relation to ambient temperature. ICES J Mar Sci: Journal du Conseil 55(5):863-877

Nakicenovic N, Swart R (eds) (2000) Emissions scenarios. 2000 special report of the intergovernmental panel on climate change. Cambridge University Press, Cambridge

Orr JC, Fabry VJ, Aumont O, Bopp L, Doney SC, Feely RA, Gnanadesikan A, Gruber N, Ishida A, Joos F, Key RM, Lindsay K, Maier-Reimer E, Matear R, Monfray P, Mouchet A, Najjar RG, Plattner G-K, Rodgers KB, Sabine CL, Sarmiento JL, Schlitzer R, Slater RD, Totterdell IJ, Weirig M-F, Yamanaka Y,
Yool A (2005) Anthropogenic ocean acidification over the twenty-first century and its impact on calcifying organisms. Nature 437(7059):681-686

Otterå $\mathrm{OH}$, Drange H, Bentsen M, Kvamsto NG, Jiang DB (2004) Transient response of the Atlantic meridional overturning circulation to enhanced freshwater input to the Nordic SeasArctic Ocean in the Bergen climate model. Tellus A Dyn Meteorol Oceanogr 56(4):342-361

Ottersen G, Loeng H (2000) Covariability in early growth and yearclass strength of Barents Sea cod, haddock, and herring: the environmental link. ICES J Mar Sci: Journal du Conseil 57(2):339-348

Ottersen G, Sundby S (1995) Effects of temperature, wind and spawning stock biomass on recruitment of Arcto-Norwegian cod. Fish Oceanogr 4(4):278-292

Ottersen G, Michalsen K, Nakken O (1998) Ambient temperature and distribution of north-east Arctic cod. ICES J Mar Sci 55:67-85

Overland JE, Spillane MC, Soreide NN (2004) Integrated analysis of physical and biological pan-Arctic change. Clim Change 63(3):291-322

Overland JE, Wang M, Salo S (2008) The recent Arctic warm period. Tellus A 60:589-597

Peterson BJ, Holmes RM, McClelland JW, Vorosmarty CJ, Lammers RB, Shiklomanov AI, Shiklomanov IA, Rahmstorf S (2002) Increasing river discharge to the Arctic Ocean. Science 298(5601):2171-2173

Rahmstorf S (2000) The thermohaline ocean circulation: a system with dangerous thresholds? An editorial comment. Clim Change 46(3):247-256

Rignot E, Kanagaratnam P (2006) Changes in the velocity structure of the Greenland ice sheet. Science 311(5763):986-990. doi: $10.1126 /$ science. 1121381

Schiermeier Q (2006) Climate change: a sea change. Nature 439(7074):256-260

Stenseth NC, Mysterud A, Ottersen G, Hurrell JW, Chan KS, Lima M (2002) Ecological effects of climate fluctuations. Science 297(5585):1292-1296

Stroeve J, Holland MM, Meier W, Scambos T, Serreze M (2007) Arctic sea ice decline: faster than forecast. Geophys Res Lett 34:L09501. doi:10.1029/2007GL029703

Toresen R, Østvedt OJ (2000) Variation in abundance of Norwegian spring-spawning herring (Clupea harengus, Clupeidae) throughout the 20th century and the influence of climatic fluctuations. Fish Fish 1:231-256

Walsh JE, Timlin MS (2003) Northern Hemisphere sea ice simulations by global climate models. Polar Res 22(1):75-82

Wang M, Overland JE (2009) A sea ice free summer Arctic within 30 years? Geophys Res Lett 36:L07502. doi:10.1029/2009 g1037820

Yin J, Schlesinger ME, Stouffer RJ (2009) Model projections of rapid sea-level rise on the northeast coast of the United States. Nat Geosci 2(4):262-266 